\title{
Laboratory Test Results Location
}

National Cancer Institute

\section{Source}

National Cancer Institute. Laboratory Test Results Location. NCI Thesaurus. Code

C119849.

The site in or on the body at which the laboratory test or result is performed or collected. 